NBER WORKING PAPER SERIES

\title{
THE ECONOMICS OF FOREIGN DIRECT INVESTMENT INCENTIVES
}

\author{
Magnus Blomström \\ Ari Kokko \\ Working Paper 9489 \\ http://www.nber.org/papers/w9489
}

\author{
NATIONAL BUREAU OF ECONOMIC RESEARCH \\ 1050 Massachusetts Avenue \\ Cambridge, MA 02138 \\ February 2003
}

The research reported here is part of the NBER program in International Studies. We thank the participants at the Conference on "Foreign Direct Investment in the Real and Financial Sector of Industrial Countries", organized by the Bundesbank, Frankfurt, May 3-4, 2002 and particularly Robert Lipsey and Jean-Louis Mucchielli for valuable comments on an earlier draft of this paper. The views expressed herein are those of the authors and not necessarily those of the National Bureau of Economic Research.

(C)2003 by Magnus Blomström and Ari Kokko. All rights reserved. Short sections of text not to exceed two paragraphs, may be quoted without explicit permission provided that full credit including notice, is given to the source. 
The Economics of Foreign Direct Investment Incentives

Magnus Blomström and Ari Kokko

NBER Working Paper No. 9489

February 2003

JEL No. J23, O12

\section{ABSTRACT}

This paper suggests that the use of investment incentives focusing exclusively on foreign firms, although motivated in some cases from a theoretical point of view, is generally not an efficient way to raise national welfare. The main reason is that the strongest theoretical motive for financial subsidies to inward FDI - spillovers of foreign technology and skills to local industry - is not an automatic consequence of foreign investment. The potential spillover benefits are realized only if local firms have the ability and motivation to invest in absorbing foreign technologies and skills. To motivate subsidization of foreign investment, it is therefore necessary, at the same time, to support learning and investment in local firms as well.

Magnus Blomström

Stockholm School of Economics

P.O. Box 6501

11383 Stockholm, Sweden

NBER and CEPR

magnus.blomstrom@hhs.se
Ari Kokko

Stockholm School of Economics

P.O. Box 6501

11383 Stockholm, Sweden

ari.kokko@hhs.se 


\title{
The Economics of Foreign Direct Investment Incentives
}

\author{
Magnus Blomström and Ari Kokko \\ Stockholm School of Economics
}

\section{Introduction}

The attitude towards inward foreign direct investment (FDI) has changed considerably over the last couple of decades, as most countries have liberalized their policies to attract investments from foreign multinational corporations (MNCs). On the expectation that foreign MNCs will raise employment, exports, or tax revenue, or that some of the knowledge brought by the foreign companies may spill over to the host country's domestic firms, governments across the world have lowered various entry barriers and opened up new sectors to foreign investment. An increasing number of host governments also provide various forms of investment incentives to encourage foreign owned companies to invest in their jurisdiction. ${ }^{1}$ These include fiscal incentives such as tax holidays and lower taxes for foreign investors, financial incentives such as grants and preferential loans to MNCs, as well as measures like market preferences, infrastructure, and sometimes even monopoly rights. ${ }^{2}$

Although some FDI promotion efforts are probably motivated by temporary macroeconomic problems such as low growth rates and rising unemployment, there are also more fundamental explanations for the increasing emphasis on investment promotion in recent years. In particular, it appears that the globalization and regionalization of the international economy have made FDI incentives more interesting and important for national governments. Trade liberalization - be it globally, through GATT and WTO, or regionally, in the form of EU, NAFTA, AFTA and other regional agreements - has led to increasing market integration and reduced the importance of market size as a determinant of investment location. Hence, even a small country may now compete for FDI, given that it can provide a sufficiently attractive incentive package. At the same time, national decision-makers have lost many of the instruments traditionally used to promote local competitiveness, employment,

\footnotetext{
${ }^{1}$ UNCTAD (2001:6-7) reports that nearly 95 percent of the 1,185 changes in national FDI legislation during the period 1991-2000 were favorable to foreign investors. A significant share of these changes focused on incentives and FDI promotion.

${ }^{2}$ See UNCTAD (1996) and Brewer and Young (1997) for definitions of various FDI incentives.
} 
and welfare. The scope for active trade policy has diminished as a result of successful trade liberalization, and the internationalization of capital markets has limited the possibilities to use exchange rate policy as a tool to influence relative competitiveness. Most clearly, this has been seen in Europe, where the Single Market program and the EMU have shifted the responsibility for trade and exchange rate policies from national governments to the EU Commission and the European Central Bank. However, national decision-makers remain committed to promoting the competitiveness and welfare of their constituencies, and are likely to put more emphasis on those policy instruments that remain at their disposal, including FDI incentives. The fact that most others subsidize foreign investment is another important reason why more and more countries are drawn into the "subsidy game".

There are also more substantial theoretical arguments in favor of public support to FDI than globalization and the wish to increase local employment and growth rates in cyclical downturns. The strongest ones are based on the prospect for knowledge spillovers. Since the technology and knowledge employed by foreign firms are to some extent public goods, foreign investment can result in benefits for their host countries even if the MNCs carry out their foreign operations in wholly-owned affiliates. These benefits take the form of various types of externalities or "spillovers". For instance, local firms may be able to improve their productivity as a result of forward or backward linkages with MNC affiliates, they may imitate MNC technologies, or hire workers trained by MNCs. The increase in competition that occurs as a result of foreign entry may also be considered a benefit, in particular if it forces local firms to introduce new technology and work harder. However, the foreign MNCs will not include these spillovers in their private assessment of the costs and benefits of investing abroad, and may therefore invest less than what would be socially optimal. The motive for public subsidies to foreign investors is to bridge the gap between the private and social returns, thus promoting larger inflows of FDI.

The aim of this paper is to examine whether international investment incentives can be justified on the basis of academic research on the host country effects of FDI. In particular, we discuss whether the externalities from the operations of foreign MNCs are strong and systematic enough to justify subsidizing foreign investment with various fiscal and financial incentives. We also discuss some alternative policy measures available for governments to benefit from inward foreign investment. 
The paper is organized as follows. Section 2 discusses the determinants of where MNCs invest and introduces the arguments for international investment incentives. Since one of the main theoretical motivations for such incentives is the potential for externalities or spillovers of FDI, Section 3 summarizes the evidence on such effects, focusing on the diffusion of production technology and labor and management skills from multinational corporations to local host country firms. Based on the current knowledge of spillovers, Section 4 asks whether investment incentives can be justified or not, and discusses the design of incentive policies. There is also a concluding section.

\section{Investment Incentives and FDI}

Theory suggests that in order to compete successfully in a foreign market a firm must possess some ownership-specific assets in knowledge, technology, organization, management, or marketing skills. A firm blessed with such assets has several alternative ways (apart from exporting) to claim the rents that they will yield in foreign markets, including subsidiary production, joint ventures, licensing, franchising, management contracts, marketing contracts, and turnkey contracts. Of these, subsidiary production and joint ventures involve varying degrees of foreign presence, and force the firm to decide where to locate their foreign activity.

Until recently, there was a strong consensus in the literature about why multinationals invest in specific locations (see e.g. Dunning, 1993, Globerman and Shapiro, 1999, and Shapiro and Globerman, 2001). The view was that MNCs are mainly attracted by strong economic fundamentals in the host economies. The most important of these are market size and the level of real income, with skill levels in the host economy, the availability of infrastructure and other resources that facilitate efficient specialization of production, trade policies, and political and macroeconomic stability as other central determinants. This hierarchy of host country characteristics largely assumed that FDI was market-seeking; it was recognized that foreign investors seeking an export base would be less focused on local market size and more concerned about the relative cost of production. Still, investment incentives were seen as relatively minor determinants of FDI decisions. While they might tilt the investment decision in favor of one of several otherwise similar investment locations, the effects were considered only marginal.

However, the views on the importance of incentives have begun to change in recent years. One indication is the proliferation of investment incentives across the world. More than 
100 countries provided various FDI incentives already in the mid-1990s, and dozens more have introduced such incentives since then - few countries compete for foreign investment without any form of subsidies today (UNCTAD 1996). In industrialized countries where financial incentives are more common, the subsidies per FDI-related job often reach tens of thousands of US dollars. For instance, summarizing data from a dozen investment location decisions in the US and EU during the period 1983-1995, UNCTAD (1995) reports financial subsidies ranging from USD 14,000 per job for Mazda's 1984 investment in Flat Rock, Michigan to USD 254,000 per job for Ford and Volkswagen investing in Setubal, Portugal in 1991. Similarly, Neven and Siotis (1993) report subsidies of about 30,000 ECUs per worker for investments in Belgium, France, and Luxembourg.

With the exception of export processing zones and industrial estates, where infrastructure and land are subsidized, developing countries are more likely to base their incentive schemes on tax holidays and other fiscal measures that do not require direct payments of scarce public funds. ${ }^{3}$ For obvious reasons, there are no reliable calculations of how costly these programs are: it is almost impossible to determine the quantity of FDI that would have flowed to each country in the absence of incentives. Due to the lack of published data on the form and amount of FDI subsidies, it is also difficult to make explicit comparisons of how different kinds of incentives influence investment flows and firm behavior, although it is likely that there significant differences between subsidy programs. For instance, direct financial subsidies are likely to have their main influence on the location decision itself, while tax holidays may well effect operational decisions for several years (in particular at the time when the tax holiday is running out). This notwithstanding, while MNC executives used to downplay the role of incentives, they now readily admit their increasing importance for investment decisions (Easson 2001:272). Moreover, recent econometric studies on the effects of FDI incentives, in particular fiscal preferences, suggest that they have become more significant determinants of international direct investment flows (e.g. Taylor 2000). ${ }^{4}$ This is

\footnotetext{
${ }^{3}$ For a discussion about the effects of export processing zones, see e.g. Johansson and Nilsson (1997), Litwack and Quian (1998), and Madani (1999). It should be noted that there is surprisingly little contact between the literature on the effects of FDI subsidies and the literature on export processing zones.

${ }^{4}$ It should be noted that the simple correlation between incentives and FDI inflows may well be negative even if incentives are significant determinants of FDI inflows. A cross-section analysis is likely to capture many cases where countries provide substantial incentives without significant inflows, because some other country has offered a more attractive investment package. In fact, a generous incentive package may sometimes be motivated by weak inflows of
} 
interesting, not least since most FDI incentives apply in particular to greenfield investments rather than foreign acquisitions of existing companies: the latter dominate aggregate FDI flows, especially in developed countries.

The main reason for the increasing prominence of FDI incentives, as noted in the introduction, is arguably the internationalization of the world economy. Global trade liberalization has made it easier for MNCs to set up international production networks, so that a larger share of output is shipped to international customers or affiliated companies in other countries rather than sold to local customers. This has reduced the impact of market size and allowed smaller countries to compete for investments that would automatically have been directed to the major markets some decades ago. Regional integration has similar effects, allowing MNCs to supply all or several member states from a single location within the region. Incentives have also become increasingly important for national policymakers who are trying to promote local production, employment, and welfare. The scope for active national trade and exchange rate policy has diminished - most clearly for present and potential EU members, who are largely bound by decisions taken by the EU Commission and the European Central Bank - and shifted attention to industrial policy, including measures such as investment incentives. As a result, the incentives provided by many countries have become more generous over the years, and "decisions that would not have been influenced by a mere two-year tax holiday may well be swayed by a 10-year holiday”(Easson 2001:272). Considering that market integration has reached further at the regional rather than global level, it is also clear that the effects of incentives are likely to be particularly strong in the competition for FDI within regions (or even countries), when the initial investment decision has been taken and the investor is choosing between alternative locations in a given region. ${ }^{5}$

The question is whether the host country's costs for providing the incentives - in terms of grants, subsidies, and other expenses - are justified. Are investment incentives likely to yield benefits that are at least as large as the costs?

To answer this question, it is convenient to begin by considering a hypothetical case where foreign MNCs do not differ in any fundamental way from local firms (although we know that MNCs typically possess firm-specific intangible assets that are not generally

FDI. See further Swenson (1998).

${ }^{5}$ It is therefore not surprising that many of the studies focusing on the effects of FDI incentives look at competition between US states or EU countries. See e.g. Coughlin et al. (1991), Grubert and Mutti (1991), Hines (1996), Neven and Siotis (1993), and Swenson (1998). 
available in the host countries). Even in this extreme case, it may be possible to construct theoretical arguments in favor of investment incentives that are based on various kinds of externalities or market imperfections. ${ }^{6}$ The costs of the initial investment incentive could arguably be recouped over time as the economy (and thereby the tax base) grows thanks to the FDI inflows. However, there are at least two arguments against this type of incentives. Firstly, it is difficult make reliable calculations about the expected future benefits in terms of growth, employment, or tax revenue, which is necessary to determine how large the subsidies should be. This is particularly complex in cases where FDI projects that are driven by investment incentives rather than economic fundamentals of the host country. The reason is that these investors are likely to be relatively footloose, and could easily decide to move on to other locations offering even more generous incentives before the expected benefits in the first location have been realized (see e.g. Flamm 1984 and McLure 1999). Secondly - and most importantly - if foreign investors do not differ in any fundamental way from local investors, subsidizing FDI may distort competition and generate significant losses among local firms. ${ }^{7}$

Thus, it is hard to justify investment incentives focusing on foreign MNCs that do not differ fundamentally from local companies. At the same time, it should be noted that this conclusion does not rule out public policy intervention in the form of investment subsidies in situations where unemployment, insufficient investment, or weak growth are central policy problems. Instead, the policy prescription is that the problems should be addressed with policies that do not differentiate between foreign and local investors.

\footnotetext{
${ }^{6}$ See e.g. Black and Hoyt (1989), where incentives are introduced by a government aiming to minimize the taxation needed to finance the provision of public services, which are produced at a decreasing average cost. Keuschnigg (1998) discusses investment externalities that arise because each investment project facilitates specialization and cost reductions among producers of intermediate goods. Since no investor can internalize the value of cost reductions, decentralized markets may result in under-accumulation of capital, motivating general investment subsidies. Similarly, Neven and Siotis (1993) provide arguments for investment subsidies in cases with imperfect labor markets, where the likelihood that unemployed workers find new jobs in the absence of FDI incentives is very low.

${ }^{7}$ Another commonly discussed problem is identifying those marginal investors that would not undertake any FDI in the absence of incentives - optimally, these are the only ones who should qualify for the incentives. However, in the hypothetical case where foreign firms do not differ from local firms, this problem does not occur. A foreign firm without any firm-specific intangible assets that sets it apart from local firms with superior knowledge of local markets, customers, and regulations would simply not invest without subsidies.
} 
In the more realistic case where conditions for foreign firms differ from those for local firms, it is easier to motivate FDI incentives with the argument that there may be some distortion or market failure that is specific to MNC production. The most obvious distortions occur if rules and regulations are biased against foreign owners - in such cases, FDI incentives may well be needed to overcome the various obstacles faced by foreign investors. Although this motive for incentives has probably been important in the past, we will simplify the subsequent discussion by assuming that there is no formal discrimination of foreign owners. ${ }^{8}$ Controlling for this, the most common source of market failure is related to externalities or spillovers of FDI. As theory suggests, a firm must possess some asset in the form of knowledge of a public-good character (for example product and process technology or management skills) to be able to compete in foreign markets. If the multinational corporation cannot capture all quasi-rents due to its productive activities in the host economy, or if the affiliate increases the competitive pressure and removes distortions, the host country's private sector can gain indirectly when productivity spills over to locally owned firms. Thus, when markets fail to reflect the social benefits of the FDI, government action can be justified to bridge the gap between social and private return for FDI projects that create positive spillovers.

Several theoretical models describing this kind of processes have appeared in recent years. For instance, Markusen and Venables (1999) present a partial equilibrium model where linkages between foreign MNCs and local suppliers of intermediate inputs reduce costs in local firms, and where the entry of foreign MNCS may in fact work as a catalyst for industrial development. While they refrain from concluding that these externalities motivate FDI subsidies, Haaland and Wooton (1999) develop a similar model in a general equilibrium framework, and focus on the policy conclusions. The entry of a foreign MNC raises the demand for domestically produced intermediates in the host country, which leads to the entry of new firms (and product varieties) in the imperfectly competitive intermediate sector, and a reduction in the cost of production. The increase in competitiveness may attract further foreign investors into the country, raising national income and welfare. This motivates the host country to subsidize FDI, in competition with other host countries that see the same potential gains. In fact, in equilibrium, the subsidies may be large enough to exhaust all the

\footnotetext{
${ }^{8}$ Moreover, FDI incentives are second-best policy responses in these cases. Clearly, the first-best policy response would be to remove the discriminating rules and regulations.
} 
gains to the host country that manages to attract the foreign investors, effectively transferring all benefits to the MNCs.

The "subsidy games" between governments aiming to attract FDI have also been subject to detailed formal analysis. One conclusion from these studies is that differences in country size, production costs, and expected gains from FDI inflows influence each country's optimal incentive scheme. ${ }^{9}$ Moreover, the equilibrium distribution of FDI between countries with subsidies may well be significantly different from that without subsidies even in a perfect information setting, where each country implements its optimal incentive scheme (Haaparanta 1996; Motta and Norman 1996; Barros and Cabral 2000). In other words, FDI incentives can be expected to have a significant impact on the pattern of international investment.

Although the rationale for subsidizing inward FDI is to correct the failure of markets to reflect spillover benefits, it should be noted that neither policy making nor formal theory have focused much effort on matching the size of subsidies to the amount of expected spillover benefits: instead, it is assumed that the spillover benefits are sufficiently large to justify investment incentives. In other words, few commentators have assessed the empirical evidence regarding spillovers in connection with this particular policy debate. This gives reason to make a brief review of literature on FDI spillovers with the explicit purpose to reinterpret the evidence in light of the debate on FDI incentives.

\section{Foreign Direct Investment and Spillovers}

The earliest discussions of spillovers in the literature on foreign direct investment date back to the 1960s. The first author to systematically include spillovers (or external effects) among the possible consequences of FDI was MacDougall (1960), who analyzed the general welfare effects of foreign investment. Other early contributions were provided by Corden (1967), who looked at the effects of FDI on optimum tariff policy, and Caves (1971), who examined the industrial pattern and welfare effects of FDI.

The common aim of these studies was to identify the various costs and benefits of FDI. Productivity externalities were discussed together with several other indirect effects that

\footnotetext{
${ }^{9}$ Another notable feature of these models is that the benefits from increasing FDI are assumed to be directly related to the amount of employment created, with little discussion of how these benefits occur and why they are related specifically to foreign investment rather than investment in general.
} 
influence the welfare assessment, such as those arising from the impact of FDI on government revenue, tax policies, terms of trade, and the balance of payments. The fact that externalities were taken into account was generally motivated by empirical evidence from case studies rather than by comprehensive theoretical arguments. Yet, the early analyses made clear that multinationals may improve allocative efficiency by entering into industries with high entry barriers and reducing monopolistic distortions, and induce higher technical efficiency if the increased competitive pressure or some demonstration effect spurs local firms to more efficient use of existing resources. They also proposed that the presence may lead to increases in the rate of technology transfer and diffusion. More specifically, case studies showed that foreign MNCs may:

- contribute to efficiency by breaking supply bottlenecks (but that the effect may become less important as the technology of the host country advances);

- introduce new know-how by demonstrating new technologies and training workers who later take employment in local firms;

- either break down monopolies and stimulate competition and efficiency or create a more monopolistic industry structure, depending on the strength and responses of the local firms;

- transfer techniques for inventory and quality control and standardization to their local suppliers and distribution channels; and,

- force local firms to increase their managerial efforts, or to adopt some of the marketing techniques used by MNCs, either on the local market or internationally.

Although this diverse list gives some clues about the broad range of various spillover effects, it says little about how common or how important they are in general. In the literature we find detailed case studies discussing various aspects of FDI in different countries and industries, and these studies often contain valuable "circumstantial evidence" of spillovers (see Blomström et al. 2000 for a survey). For instance, many analyses of the linkages between MNCs and their local suppliers and subcontractors have documented learning and technology transfers that may make up a basis for productivity spillovers or market access spillovers. However, these studies seldom reveal whether the MNCs are able to extract all the benefits that the new technologies or information generate among their supplier firms, so there is no clear proof of spillovers, but it is reasonable to assume that spillovers are positively related to the extent of linkages. Similarly, there is much written on the relation between MNC entry 
and presence and market structure in host countries, and this is closely related to the possible effects of FDI on competition in the local markets. There are also case studies of demonstration effects, technology diffusion, and labor training in foreign MNCs. However, although these studies provide much detailed information about the various channels for spillovers, they say little about the importance of such spillovers.

The statistical studies of spillovers, by contrast, may reveal the overall impact of foreign presence on the productivity of local firms, but they are generally not able to say much about how the effects come about. These studies typically estimate production functions for locally owned firms, and include the foreign share of the industry as one of the explanatory variables. They then test whether foreign presence has a significant positive impact on local productivity (or productivity growth) once other firm and industry characteristics have been accounted for. Although the data used in these analyses are often limited to few variables, aggregated to industry level rather than plant level, and in several cases of a cross-section rather than time-series or panel character, they do provide some important evidence on the presence and pattern of spillover effects.

Almost all of the statistical analyses of spillovers have focused on intra-industry effects, but there are a few exceptions. One of them is Katz (1969), who notes that the inflow of foreign capital into the Argentine manufacturing sector in the 1950s had a significant impact on the technologies used by local firms. He asserts that the technical progress did not only take place in the MNCs' own industries, but also in other sectors, because the foreign affiliates forced domestic firms to modernize "by imposing on them minimum standards of quality, delivery dates, prices, etc. in their supplies of parts and raw materials" (Katz 1969, p. 154). Also Aitken and Harrison (1991) include some discussion about inter-industry effect in Venezuelan manufacturing, and argue that forward linkages generally brought positive spillover effects, but that backward linkages appeared to be less beneficial because of the foreign firms' high import propensities (although there were differences between industrial sectors). Moreover, Sjöholm (1999b) identifies a geographical dimension of positive interindustry spillovers in Indonesian manufacturing. His results suggest that the presence of foreign multinational companies may raise the productivity of locally owned firms in other industries, presumably through various linkages, but only if they are located in close proximity of the foreign multinationals. Also Kugler (2001), which is probably the most comprehensive study of the sectoral diffusion of spillovers from FDI, finds that the greatest 
impact of MNCs in Colombian manufacturing is across rather than within the subsidiaries own industries. However, the subsequent discussion will rarely touch upon this kind of interindustry links, but rather focus on intra-industry effects. To the extent that FDI affects other industries than that where the foreign investor operates, it is obvious that there is a risk that effects - negative as well as positive - are underestimated.

The earliest statistical analyses of intra-industry spillovers include studies for Australia by Caves (1974), for Canada by Globerman (1979), and for Mexico by Blomström and Persson (1983). These authors examine the existence of spillovers by testing whether foreign presence has any impact on labor productivity in local firms in a production function framework. Foreign presence is simply included among other firm and industry characteristics as an explanatory variable in a multiple regression. All three studies conclude that spillovers are significant at this aggregate level, although they cannot say anything about how spillovers take place.

Some more recent studies also claim that inward investment has made an important and significant contribution to economic growth in the recipient countries. For instance, Driffield (2001), Liu et al. (2000) and Pain (2001) all find statistically significant spillovers in the UK, as do Chuang and Lin (1999), Dimelis and Louri (2002), and Lipsey and Sjöholm (2001) in their studies of Greece, Taiwan, and Indonesia, respectively. Similar results are reported in Blomström and Wolff (1994), who also try to determine the size of these effects by asking whether the spillovers in the Mexican manufacturing sector were large enough to help Mexican firms converge toward US productivity levels during the period 1965-1982. Their answer is affirmative: foreign presence seems to have a significant positive impact on the rates of growth of local productivity. Similar conclusions is reached by Nadiri (1991), in a study of the impact of US direct investment in plant and equipment on the manufacturing sectors in France, Germany, Japan, and the UK between 1968 and 1988. Increases in the capital stock owned by US multinationals seem to stimulate new domestic investment in plant and equipment, and it appears that there is also a positive impact of FDI on the growth of total factor productivity in the host countries' manufacturing sectors.

On the other hand, there are several studies that find negative effects of the presence of multinationals on domestic firms. For instance, Haddad and Harrison (1991, 1993), in a test of the spillover hypothesis for Moroccan manufacturing during the period 1985-1989, conclude that spillovers do not take place in all industrial sectors. Like Blomström (1986), 
they find that foreign presence lowers the average dispersion of a sector's productivity, but they also observe that the effect is more significant in sectors with simpler technology. This is interpreted to mean that foreign presence forces local firms to become more productive in sectors where best practice technology lies within their capability, but that there are no significant transfers of modern technology. Furthermore, they find no significant effects of foreign presence on the rate of productivity growth of local firms, and interpret this as additional support to the conclusion that technology spillovers do not occur.

Aitken and Harrison $(1991,1999)$ use plant-level data for Venezuelan manufacturing between 1976 and 1989 to test the impact of foreign presence on total factor productivity growth. They conclude that domestic firms exhibited higher productivity in sectors with a larger foreign share, but argue that it may be wrong to conclude that spillovers have taken place if MNC affiliates systematically locate in the more productive sectors. In addition, they are also able to perform some more detailed tests of regional differences in spillovers. Examining the geographical dispersion of foreign investment, they suggest that the positive impact of FDI accrued mainly to the domestic firms located close to the MNC affiliates. However, effects seem to vary between industries.

Also Perez (1998), in a study of UK industries and Cantwell (1989), who investigates the responses of local firms to the increase in competition caused by the entry of US multinationals into European markets between 1955 and 1975, argue that positive technology spillovers did not occur in all industries. Cantwell's analysis differs notably from the other studies discussed in this section - he does not focus on productivity, but rather on changes in the market shares of foreign and local firms - but his conclusions are interesting. He asserts that "the technological capacity of indigenous firms ... was the major factor in determining the success of the European corporate response" (p. 86) to the US challenge, and that the size of the national market was an additional determinant. More specifically, Cantwell suggests that the entry of US affiliates provided a highly beneficial competitive spur in the industries where local firms had some traditional technological strength, whereas local firms in other industries - especially in countries where markets were too small to allow both kinds of firms to operate at efficient scale - were forced out of business or pushed to market segments that were ignored by the foreign MNCs.

So the results on the presence of spillovers seem to be mixed. However, recent studies suggest that there is a systematic pattern where various host industry and host country 
characteristics influence the incidence of spillovers. For instance, the foreign affiliates' levels of technology or technology imports seem to influence the amount of spillovers to local firms. The technology imports of MNC affiliates, in turn, have been shown to vary systematically with host country characteristics. These imports seem to be larger in countries and industries where the educational level of the local labor force is higher, where local competition is tougher, and where the host country imposes fewer formal requirements on the affiliates' operations (Blomström et al. 1994; Kokko and Blomström 1996).

Some recent studies have also addressed the apparent contradictions between the earlier statistical spillover studies by exploring the hypothesis that the host country's level of technical development may matter as a starting point. Kokko (1994), for example, argues that spillovers should not be expected in all kinds of industries. In particular, foreign MNCs may sometimes operate in "enclaves", where neither products nor technologies have much in common with those of local firms. In such circumstances, there may be little scope for learning, and spillovers may not materialize. Conversely, when foreign affiliates and local firms are in more direct competition with each other, spillovers are more likely.

Examining data for Mexican manufacturing, Kokko (1994) finds that spillovers are positively related to the host economy's capacity to absorb them. Similar findings for the Uruguayan manufacturing sector are reported in Kokko et al. (1996), although their study suggests that weak technological capability at the firm level may also be an obstacle for spillovers. This is consistent with some recent research results from Ireland and India. Görg and Strobl (2000 and 2001) show that the presence of foreign companies in the Irish economy has a life enhancing effect on indigenous firms and plants in high tech industries, suggesting the presence of technological spillovers, but no effect on indigenous low tech firms and plants. Kathuria $(1998,2000)$ suggests that the indirect gains or spillovers from FDI are not an automatic consequence of MNC presence in the Indian economy. Rather they depend to a large extent on the efforts of local firms to invest in learning and R\&D activities so as to decodify the spilled knowledge. Moreover, no evidence of spillovers to low-tech Indian companies was reported.

Another possible explanation for the divergent findings from the earlier statistical spillover tests is suggested by Kokko (1996), who analyzes the effects of competition in Mexican manufacturing. The earlier studies have tested the hypothesis that productivity spillovers are strictly proportional to foreign presence, but Kokko argues that this is not 
always the case. Spillovers from competition, in particular, are not determined by foreign presence alone, but rather by the simultaneous interactions between foreign and local firms. Hence, it is possible that the spillovers are larger in cases where a few foreign MNC stir up a previously protected market than in a situation where foreign affiliates hold large market shares, but refrain from competing hard with local firms. In fact, in some cases, large foreign presence may even be a sign of a weak local industry, where local firms have not been able to absorb any productivity spillovers at all and have therefore been forced to yield market shares to the foreign MNCs. Analyzing the operations of foreign and domestic firms in Mexican manufacturing in a simultaneous framework, Kokko (1996) finds support for these hypotheses. The labor productivity of foreign and local firm appears to be simultaneously determined, and competition from foreign affiliates seems to have an independent effect on the productivity of local firms, even after accounting for the demonstration and contagion spillovers that are directly proportional to foreign presence. Sjöholm (1999a) also concludes that competition enhances the positive productivity spillovers from FDI.

Yet another possible determinant of spillovers is the trade orientation of the investing firms. Kokko et al. (2001) note that local market oriented foreign investors in Uruguay have apparently had a stronger impact on local technology and productivity levels than have export oriented local firms. One reason could be that local market oriented MNCs may have relatively strong interactions with local firms, both as competitors and collaborators, whereas export oriented foreign investors may often be relatively isolated from the local market. ${ }^{10}$

While most of the studies mentioned above have focused on differences between industries in a given host country, Blomström et al. (1994) have examined the role of the host country's overall development level as a determinant of spillovers. The results of their comprehensive cross-country study of 101 economies suggest that spillovers are concentrated to middle-income developing countries, while there was no evidence of such effects for the poorest developing countries. Just as the analyses of individual host countries, these findings highlight the importance of local competence and competition for spillovers. Few local firms in the poorest countries are in direct competition with foreign MNCs, and few of these countries possess the technical skills needed to absorb modern MNC technologies. Similar

\footnotetext{
${ }^{10}$ Kokko et al. (2001) also suggest that the externalities from FDI may also take the form of export spillovers, so that local firms in industries with exporting foreign MNCs also learn to be successful in export markets. There are few other studies of such export effects, but is should be noted that spillover benefits must not necessarily be related to production technology: the potential for gains in marketing, distribution, and other areas is also great.
} 
results are reported in Balasubramanyam (1998). He concluded that FDI can be a potent instrument of development, but only in the presence of a threshold of human capital, well developed infrastructure facilities, and a stable economic climate. Thus, "FDI is a rich country good" (p. 18) and only the most advanced developing countries are able to benefit from FDI.

It seems clear from these studies that host country and host industry characteristics determine the impact of FDI, and that systematic differences between countries and industries should therefore be expected. There is strong evidence pointing to the potential for significant spillover benefits from FDI, but also ample evidence indicating that spillovers do not occur automatically. A reasonable conclusion from the mixed findings of earlier studies is that the ability and motivation of local firms to engage in investment and learning to absorb foreign knowledge and skills is an important determinant of whether or not the potential spillovers will be realized.

\section{Are International Investment Incentives Justified?}

Based on the argument that foreign firms can promote economic development and growth, many countries have introduced various investment incentives to encourage foreign MNCs to invest in their market. As we argued in Section 2, such incentives can mainly be justified if the foreign firms differ from local companies in that they possess some firm specific intangible asset that can spill over to local firms. In that case, the foreign investor's private benefits are lower than the social benefits (including the spillovers) and total foreign investment will fall short of the optimal amount unless various investment incentives compensate the foreign investor. Given the positive empirical evidence on spillovers presented in Section 2, there are therefore reasonable arguments in favor of investment incentives.

At the same time, there are good reasons to remain cautious in granting incentives focusing exclusively on foreign investors. We have seen above that it is not easy to determine where and how spillovers will occur, which creates problems of "picking winners", i.e. identifying firms that are likely to yield spillover benefits. It is also difficult to calculate the value of these externalities, which is important, since national welfare will increase only if the investment incentive is smaller than the value of the externality. If the subsidies are larger than what is motivated by the externalities, the host country will not only lose public revenue, 
but the incentives will also discriminate against local firms that may lose jobs and market shares, as noted in Section 3.

Another problem with international investment incentives is that they prepare the ground for rent seekers. It is well known from the trade literature that selectivity, in combination with lack of transparency, increases the risk for rent-seeking and corruption (see e.g. Bhagwati 2001). Policy measures that focus on broad and general forms of support that are available to all firms, irrespective of nationality, tend to reduce rent-seeking and corruption (see Kokko 2002). Some of the main problems in this context are related tax holidays and tax breaks, which may appear to be simple and innocuous forms of incentives. However, they are likely to lead to transfer pricing and other distortions as firms try to shift as many transactions as possible to the sector or activity with low or no taxes, or set up new firms as the tax preferences of existing firms expire (McLure 1999).

Moreover, competition among governments (national or local) to attract FDI may create problems (see Oman 2000). When most governments compete actively for FDI, it is difficult for any individual country to stay out of bidding contests, which effectively shift profits from the host country to multinational enterprises. One reason is of course that strong promotion efforts show that the government is actively doing something to strengthen employment, productivity, growth, or some other policy objective (whether or not they get any FDI). Another reason is that some of the perceived benefits (in particular, the jobs created by FDI) are easily observable while some of the costs (particularly related to tax breaks and other fiscal incentives) are distributed over long periods of time and hard to measure.

Consequently, there is a tendency to overbid and the subsidies may very well surpass the level of spillover benefits, with welfare losses as a result.

These problems are in many ways similar to those discussed in the trade policy debate. In the same way as investment incentives may be politically attractive in the short run, but costly in the long run, protectionism may also promote local employment and production in the short run at a high long run cost. In fact, several authors have drawn parallels between trade barriers and international investment subsidies, noting, for example, that it is possible to calculate tariff equivalents for each FDI subsidy (Bond and Guisinger 1985; Huizinga 1991). Both policy areas are also characterized by coordination problems, where no country gains 
from unilateral liberalization unless they expect others to follow. ${ }^{11}$ In the trade area, the path away from beggar-thy-neighbor policies has been multilateral negotiations where trade liberalization is coordinated across countries. It is clear that a similar solution would be first best also in foreign direct investment policy, in particular at the regional level (where competition is most fierce). ${ }^{12}$ However, although several multilateral agreements include clauses on incentives and investment rules, their coverage remains limited. For instance, the WTO regulates FDI incentives in its agreements on Subsidies and Countervailing Measures (SCMs) and Trade-Related Investment Measures (TRIMS), but these agreements leave much discretion to national decision-makers, and apply only to "specific subsidies" that are directed to individual enterprises. ${ }^{13}$ The OECD tried to negotiate a more ambitious Multilateral Agreement on Investment (MAI) during the second half of the 1990s, but these negotiations did not yield any results. More comprehensive regulation of FDI incentives is found only in advanced regional integration agreements like NAFTA and EU, where extensive market integration has made it necessary to harmonize incentive policies as well. For instance, in the EU, investment incentives are in principle restricted to areas qualifying for regional assistance. This notwithstanding, substantial subsidies - amounting to tens of thousands of Euros per job created - are common, and restrictions on subsidies are eased when EU governments explicitly compete for FDI with non-EU countries (Brewer and Young 1997).

In the absence of multilateral agreements on investment, it is therefore likely that many countries will continue subsidizing FDI. How should FDI incentives then be designed? The most important argument against investment incentives focusing exclusively on foreign firms is based on the evidence from Section 3 that spillovers are not automatic, but depend crucially on the conditions for local firms. The potential for spillovers is not likely to be realized unless local firms have the ability and motivation to learn from foreign MNCs and to invest in new

\footnotetext{
${ }^{11}$ For instance, Head et al. (1999) show that unilateral withdrawal of investment incentives 1980-1992 would have been costly for any individual US state, although the overall impact on the geographical distribution of inward FDI was small. The reason is that the promotional policies of various US states tended to offset each other.

${ }^{12}$ There is no obvious reason why the coordinated FDI subsidies should be set equal to zero, particularly considering intra-regional competition for FDI from the rest of the world. In fact, Barros and Cabral (2000) show that policy coordination with jointly optimal (non-zero) subsidies yields higher welfare than either unrestricted competition or complete harmonization with subsidies set at zero.

${ }^{13}$ In principle, the SCM agreement prohibits subsidies that are contingent on export performance and use local inputs, and restricts the use of firm-specific subsidies exceeding 15 percent of total investment cost. See Brewer and Young (1997) and Mah and Tamulaitis (2000).
} 
technology. Consequently, investment incentives aiming to increase the potential for spillovers may be inefficient unless they are complemented with measures to improve the local learning capability and to maintain a competitive local business environment.

This suggests first and foremost that the incentives should be rules-based and available on equal terms to all investors irrespective of industry and nationality of investor, rather than based on discretionary decisions. The motive for supporting foreign investors - including existing investors that may consider expanding their activities - is to equalize social and private returns to investment. But there is a difference between social and private returns only if local firms are actually able to absorb some of the potential spillover benefits, and this does not occur automatically. Hence, to justify FDI incentives, there is a reason to simultaneously subsidize local firms to strengthen their capacity to absorb foreign technology and skills.

Moreover, the incentives should ideally not be of an ex ante type that is granted and paid out prior to the investment, but should instead promote those activities that create a potential for spillovers. In particular, these include education, training, and R\&D activities, as well as linkages between foreign and local firms. ${ }^{14}$ An advantage of performance based incentives is that they may affect the entire stock of investments, rather than just the flow of new investment. An added advantage of focusing on education, training, and R\&D is that these measures are compatible with WTO's agreement on SCMs. Given their broad scope, the investment incentives in question should be considered part of the economy's innovation and growth policies rather than a policy area that is only of relevance for foreign investors.

In addition to investment incentives of the type discussed above, governments should also consider their efforts to modernize infrastructure, raise the level of education and labor skills, and improve the overall business climate as parts of their investment promotion policy. As noted repeatedly above, these are important component of the economic fundamentals that determine the location of FDI. In addition to attracting FDI and facilitating the realization of spillovers, these policies will also promote growth and development of local industry. This, after all, is one of the ultimate goals of government intervention in general.

Ireland seems to be an excellent example of the advantages of such policies. There is no doubt that the Irish success in attracting FDI and benefiting from such investments, to a large extent stems from having the right "fundamentals" (see e.g. Barry, et al., 1999). Ireland has for a long time been considered a preferred location for FDI, but it should be noted that the

${ }^{14}$ UNCTAD (2001) includes a detailed discussion about policies to promote linkages between foreign and local firms. 
various incentives attracting foreign investors, including low taxes, good infrastructure, access to the EU market, and continuously increasing labor skills, have also been available to local companies. This is a likely reason for the positive effects of inward FDI on local industry as found by e.g. Görg and Strobl (2000 and 2001). Another example is provided by Sweden, which was the world $7^{\text {th }}$ largest recipient of foreign investment during the second half of the 1990s. While Sweden provides an attractive business environment, its industrial policies do not distinguish between foreign and domestic investors.

\section{Concluding Remarks}

Foreign direct investment can play an important role in raising a country's technological level, creating new employment, and promoting economic growth. Many countries are therefore actively trying to attract foreign investors in order to promote their economic development, particularly at times when the country's domestic growth prospects appear weak. However, designing efficient incentive programs is complicated task, and the competition between host government trying to attract FDI is likely to complicate the task further, as it tends to shift profits and welfare from the host countries to foreign multinationals. A first-best solution for FDI incentive policy may therefore be multilateral policy coordination to set the "rules of the game", in the same way as GATT/WTO has defined the rules for international trade policy. In fact, countries participating in regional integration agreements that go beyond GATT/WTO rules - most notably the European Union - have realized the need to harmonize the use of investment incentives and introduced specific guidelines for their use.

The failure of OECD's MAI initiative has, however, demonstrated that it will be difficult to achieve a broad multilateral solution in this area. Consequently, many countries will continue using FDI incentives as important policy tools. In this paper we have argued that the use of investment incentives focusing exclusively on foreign firms, although motivated in some cases from a theoretical point of view (and in even more cases from political considerations), is generally not an efficient way to raise national welfare. The main reason is that the strongest theoretical motive for financial subsidies to inward FDI spillovers of foreign technology and skills to local industry - is not an automatic consequence of foreign investment. The potential spillover benefits are realized only if local firms have the ability and motivation to invest in absorbing foreign technologies and skills. To motivate 
subsidization of foreign investment, it is therefore necessary, at the same time, to support learning and investment in local firms as well.

Hence, rather than proposing narrowly defined FDI policies, we argue that good governance in the area of FDI policy is to consider the investment incentive packages as part of the country's overall industrial policy, and make any incentives available on equal terms to all investors, foreign as well as local. The incentives should focus in particular on those activities that create the strongest potential for spillovers, including linkages between foreign and local firms, education, training, and R\&D. It should also be noted that the country's industrial policies in general are important determinants of FDI inflows and effects of FDI. By enhancing the local supply of human capital and modern infrastructure and by improving other fundamentals for economic growth, a country does not only become a more attractive site for multinational firms, but there is increased likelihood that its private sector benefits from the foreign participation through spillover benefits.

\section{References}

Aitken, B. and A. Harrison (1991), "Are There Spillovers From Foreign Direct Investment? Evidence from Panel Data for Venezuela", mimeo, MIT and the World Bank, November.

Aitken, B. and A. Harrison (1999), 'Do Domestic Firms Benefit from Foreign Investment? Evidence from Venezuela", American Economic Review, Vol. 89, 605-618.

Balasubramanyam, V.N. (1998), "The MAI and Foreign Direct Investment in Developing Countries", Discussion Paper EC10/98, Lancaster University.

Barros. P.P. and L. Cabral (2000), "Competing for Foreign Direct Investment”, Review of International Economics, Vol. 8, 360-371.

Barry, F., J. Bradley and E.O'Malley (1999), "Indigenous and Foreign Industry:

Characteristics and Performance", in F. Barry, ed., Understanding Ireland 's Economic Growth, London: Macmillan.

Bhagwati, J. (2001), Free Trade Today, Princeton: Princeton University Press.

Black, D. and W. Hoyt (1989), "Bidding for Firms", American Economic Review, Vol. 79, 1249-1256.

Blomström, M. (1986), "Foreign Investment and Productive Efficiency: The Case of Mexico", Journal of Industrial Economics, Vol. 15, 97-110.

Blomström, M., A. Kokko and M. Zejan (1994), "Host Country Competition and Technology Transfer by Multinationals“, Weltwirtschaftliches Archiv, Band 130, 521-533.

Blomström, M., A. Kokko and M. Zejan (2000), Foreign Direct Investment. Firm and Host Country Strategies, London: Macmillan. 
Blomström, M. and H. Persson (1983), "Foreign Investment and Spillover Efficiency in an Underdeveloped Economy: Evidence from the Mexican Manufacturing Industry”,

World Development, Vol. 11, 493-501.

Blomström, M. and E. Wolff (1994), "Multinational Corporations and Productivity Convergence in Mexico", in W. Baumol, R. Nelson and E. Wolff, eds., Convergence of Productivity: Cross-National Studies and Historical Evidence, Oxford: Oxford University Press.

Bond, E.W. and S.E. Guisinger (1985), "Investment Incentives as Tariff Substitutes: A Comprehensive Measure of Protection", Review of Economics and Statistics, Vol. 67, 91-97.

Brewer, T.L. and S. Young (1997), "Investment Incentives and the International Agenda", World Economy, Vol. 20, 175-198.

Cantwell, J. (1989), Technological Innovation and Multinational Corporations, Oxford: Basil Blackwell.

Caves, R.E. (1971), 'International Corporations: The Industrial Economics of Foreign Investment", Economica, Vol. 38, 1-27.

Caves, R.E. (1974), "Multinational Firms, Competition and Productivity in Host-Country Markets", Economica, Vol. 41, 176-193.

Chuang, Y-C and C-M Lin (1999), "Foreign Direct Investment, R\&D and Spillover Efficiency: Evidence from Taiwan's Manufacturing Firms", Journal of Development Studies, Vol. 35, 117-137.

Coughlin, C.C., J.V. Terza, and V. Arromdee (1991), "State Characteristics and the Location of Foreign Direct Investment within the United States", Review of Economics and Statistics, Vol. 65, 675-683.

Dimelis, S. and Louri, H. (2002), "Foreign Ownership and Production Efficiency: A Quantile Regression Analysis", Oxford Economic Papers (forthcoming).

Driffield, N. (2001), "The Impact on Domestic Productivity of Inward Investment in the UK", Manchester School, Vol. 69 (1), 103-119.

Dunning, J. (1980), "Toward an Eclectic Theory of International Production: Some Empirical Tests", Journal of International Business Studies, Vol. 11, 9-31.

Dunning, J. (1993), Multinational Enterprises and the Global Economy, Reading: AddisonWesley Publ. Co.

Easson, A. (2001), "Tax Incentives for Foreign Direct Investment Part 1: Recent Trends and Countertrends", Bulletin for International Fiscal Documentation, Vol. 55, 266-274.

Flamm, K. (1984), The Volatility of Offshore Production", Journal of Development Economics, Vol. 16 (December), 231-248.

Globerman, S. (1979), 'Foreign Direct Investment and 'Spillover' Efficiency Benefits in Canadian Manufacturing Industries", Canadian Journal of Economics, Vol. 12, 42-56.

Globerman, S. and D. Shapiro (1999), "The Impact of Government Policies on Foreign Direct Investment: The Canadian Experience", Journal of International Business Studies, Vol. $30(3), 513-532$.

Grubert, H. and J. Mutti (1991), "Taxes, Tariffs and Transfer Pricing in Multinational Corporate Decision Making”, Review of Economics and Statistics, Vol. 73, 285-293.

Görg, H. and E. Strobl (2000), "Multinational Companies, Technology Spillovers, and Firm Survival: Evidence from Irish Manufacturing”, GLM Research Paper 2000/18, University of Nottingham. 
Görg, H. and E. Strobl (2001), "Multinational Companies, Technology Spillovers, and Plant Survival: Evidence from Irish Manufacturing”, EIJS Working Paper 131, Stockholm School of Economics.

Haaland, J.I. and I. Wooton (1999), "International Competition for Multinational Investment", Scandinavian Journal of Economics, Vol. 101, 631-649.

Haaparanta, P. (1996), "Competition for Foreign Direct Investments", Journal of Public Economics, Vol. 63, 141-153.

Haddad, M. and A. Harrison (1991), "Are there Positive Spillovers from Direct Foreign Investment? Evidence from Panel Data for Morocco", mimeo, Harvard University and the World Bank, September.

Haddad, M. and A. Harrison (1993), "Are there Positive Spillovers from Direct Foreign Investment? Evidence from Panel Data for Morocco", Journal of Development Economics, Vol. 42, 51-74.

Head, C.K., J.C. Ries and D.L. Swenson (1999), "Attracting Foreign Manufacturing: Investment Promotion and Agglomeration", Regional Science and Urban Economics, Vol. 29, 197-218.

Hines, J.R. (1996), "Altered States: Taxes and the Location of Foreign Direct Investment in America”, American Economic Review, Vol. 86, 1076-1094.

Huizinga, H. (1991), "Foreign Investment Incentives and International Cross-Hauling of Capital", Canadian Journal of Economics, Vol. 24, 710-716.

Johansson, H. and L. Nilsson (1997), "Export Processing Zones as Catalysts”, World Development, Vol. 25, 2115-2128.

Kathuria, V. (1998), "Foreign Firms and Technology Transfer Knowledge Spillovers to Indian Manufacturing Firm”, INTECH Discussion Paper Series No. 9804, United Nations University, January.

Kathuria, V. (2000), "Productivity Spillovers from Technology Transfer to Indian Manufacturing Firms", Journal of International Development, Vol. 12, pp. 343-369..

Katz, J.M. (1969), Production Functions, Foreign Investment and Growth, Amsterdam: North Holland.

Keuschnigg, C. (1998), "Investment Externalities and a Corrective Subsidy”, International Tax and Public Finance, Vol. 5, 449-469.

Kindleberger, C.P. (1969), American Business Abroad, New Haven: Yale University Press.

Kokko, A. (1994), 'Technology, Market Characteristics, and Spillovers", Journal of Development Economics, Vol. 43, 279-293.

Kokko, A. (1996), "Productivity Spillovers from Competition between Local Firms and Foreign Affiliates", Journal of International Development, Vol. 8, pp. 517-530.

Kokko, A. (2002), "Export-Led Growth in East Asia: Lessons for Europe's Transition Economies", EIJS Working Paper No. 142, Stockholm School of Economics, February.

Kokko, A. and M. Blomström (1995), "Policies to Encourage Inflows of Technology through Foreign Multinationals", World Development, Vol. 23, 459-468.

Kokko, A., R. Tansini and M. Zejan (1996), "Local Technological Capability and Spillovers from FDI in the Uruguayan Manufacturing Sector", Journal of Development Studies, Vol. 34, 602-611.

Kokko, A., R. Tansini and M. Zejan (2001), "Trade Regimes and Effects of FDI: Evidence from Uruguay", Weltwirtschaftlishers Archiv, Vol. 137, 124-149.

Kugler, M. (2001), "The Sectoral Diffusion of Spillovers from Foreign Direct Investment", Mimeo, University of Southampton, August. 
Lipsey, R.E. and F. Sjöholm (2001), "Foreign Direct Investment and Wages in Indonesian Manufacturing", NBER Working Paper No 8299 (May).

Litwack, J.M. and Yingyi Qian (1998), "Balanced or Unbalanced Development: Special Economic Zones as Catalysts for Transition", Journal of Comparative Economics, Vol. 26, 117-141.

Liu, X. and P. Siler, C. Wang and Y. Wei (2000), "Productivity Spillovers from Foreign Direct Investment: Evidence from UK Industry Level Panel Data", Journal of International Business Studies, Vol. 31 (3), 407-425.

MacDougall, G.D.A. (1960), "The Benefits and Costs of Private Investment from Abroad: A Theoretical Approach", Economic Record, Vol. 36, 13-35.

Madani, D. (1999), "A Review of the Role and Impact of Export Processing Zones", Policy Research Working Paper No. 2238, The World Bank, Washington, D.C..

Mah, J.S. and D. Tamulatis (2000), "A Note on Investment Incentives in the WTO and the Transition Economies", Post-Communist Economies, Vol. 12, 119-130.

Markusen, J.R. and A.J. Venables (1999), "Foreign Direct Investment as a Catalyst for Industrial Development", European Economic Review, Vol. 43, 335-356.

McLure, C.E. (1999), "Tax Holidays and Investment Incentives; A Comparative Analysis", Bulletin for International Fiscal Documentation, Vol. 53, 326-339.

Motta, M. and G. Norman (1996), "Does Economic Integration Cause Foreign Direct Investment", International Economic Review, Vol. 37, 757-783.

Nadiri, M.I. (1991), "U.S. Direct Investment and the Production Structure of the Manufacturing Sector in France, Germany, Japan, and the U.K.", mimeo, New York University and NBER, December.

Neven, D. and G. Siotis (1993), "Foreign Direct Investment in the European Community: Some Policy Issues", Oxford Review of Economic Policy, Vol. 20, 72-93.

Oman, C. (2000), Policy Competition for Foreign Direct Investment: A Study of Competition among Governments to Attract FDI, Paris: OECD.

Pain, N., ed. (2001), Inward Investment, Technological Change and Growth. The Impact of Multinational Corporations on the UK Economy, Houndsmills: Pelgrave.

Perez, T. (1998), Multinational Enterprises and Technological Spillovers, The Netherlands: Harwood Academic Publishers.

Shapiro, D. and S. Globerman (2001), "National Infrastructure and Foreign Direct Investment", mimeo, Simon Fraser University (February).

Sjöholm, F. (1999a), "Technology Gap, Competition and Spillovers from Direct Foreign Investment: Evidence from Establishment Data", Journal of Development Studies, Vol. $36(1), 53-73$.

Sjöholm, F. (1999b), "Productivity Growth in Indonesia: The Role of Regional Characteristics and Direct Foreign Investment", Economic Development and Cultural Change, Vol. 47 (3), 559-584.

Swenson, D.L. (1998), "The Effect of U.S. State Tax and Investment Promotion Policy on the Distribution of Inward Investment", in R.E. Baldwin, R.E. Lipsey, and J.D. Richardson, eds., Geography and Ownership as Bases for Economic Accounting, Chicago: University of Chicago Press.

Taylor, C.T. (2000), "The Impact of Host Country Government Policy on US Multinational Investment Decisions", World Economy, Vol. 23, 635-648.

UNCTAD (1995), World Investment Report 1995: Transnational Corporations and Competitiveness, New York and Geneva; United Nations. 
UNCTAD (1996), Incentives and Foreign Direct Investment, Current Studies, Series A, No. 30, New York and Geneva: United Nations.

UNCTAD (2001), World Investment Report 2001: Promoting Linkages, New York and Geneva: United Nations. 